\title{
Influence of biodiesel blends produced in Colombia on a Diesel engine
}

\author{
O. Venegas ${ }^{1}$ and L.F. Mónico ${ }^{1}$ \\ ${ }_{1}^{1}$ Program of Mechanical Engineering, Escuela Colombiana de Ingeniería Julio Garavito, 111166 Bogotá D.C., Colombia \\ Phone: +5716683600
}

\begin{abstract}
Diesel engines have dominated the heavy duty and passenger vehicle market in the past 30 years. Consequently, the oil-derived fuels demand and the amount of pollutant emissions have witnessed exponential growth during the last three decades. Although Diesel engines present the advantage of higher efficiency and, therefore, lower levels of $\mathrm{CO}_{2}$ emissions, they produce high levels of NOx and particulate matter. In order to face these difficulties, the use of alternative fuels started booming in the early 2000 s and continue to gain influence today. Biodiesel stands out from the alternative fuels' selection for its ease of use, production, storage and potential to reduce levels of particles, $\mathrm{CO}, \mathrm{HC}$ and $\mathrm{CO}_{2}$. The main goal of this research is to experimentally determine the influence of palm oil biodiesel produced in Colombia on a Diesel engine's behavior in terms of engine performance and pollutant emissions. As different mixtures of commercial Diesel and biodiesel at different operating conditions were tested, the results showed that it is possible to maintain the engine's performance at acceptable levels and to, in some cases, reduce smoke density and NOx levels.
\end{abstract}

ARTICLE HISTORY

Received: $31^{\text {st }}$ July 2020

Revised: $02^{\text {nd }}$ Apr 2021

Accepted: $13^{\text {th }}$ Apr 2021

\section{KEYWORDS}

biodiesel;

palm oil;

Diesel;

performance;

emissions;

alternative internal

combustion engine.

\section{INTRODUCTION}

In a world where the use of fossil fuels dominates almost every industry, different sectors worldwide have faced countless environmental challenges and have been forced to implement new energetic solutions in recent years. Since the early 90s, the use of Diesel vehicles has grown, causing an increase in the demand for petroleum-based fuel and, consequently, of pollutants emissions. Compared to gasoline engines, Diesel engines present the advantage of being more efficient. As such, although they emit less $\mathrm{CO}_{2}$, they produce higher levels of $\mathrm{NO}_{\mathrm{x}}$ and particulates [1].

Alternative energy sources should be sought to prepare us for the uncharted future of fossil fuel scarcity [2]. The use of alternative fuels, biodiesel being chief among them, is one of the most popular alternatives explored to date and with growing usage in the transportation sector [3]. Since it is relatively easy to transform vegetable oils into biodiesel through a transesterification process, this type of fuel attracts the attention of the scientific community for its ease of use, production (transesterification process [4]), storage, is a renewable, biodegradable and non-toxic fuel, and potential to reduce particles, $\mathrm{CO}, \mathrm{HC}$ and $\mathrm{CO}_{2}$ emissions [5-8]. In the last ten years, Colombia has been working with cleaner fuels increasing the use of palm oil biodiesel, showing in 2019 an average demand of 45.000 tons per month [9].

Therefore, the goal of this research is to determine the influence of palm oil biodiesel produced in Colombia in a Diesel old generation engine (pre-Euro), still used in the Colombian market. In order to achieve this objective, experimental studies have been carried out to obtain engine performance and levels of pollutant emissions when different biodiesel and standard Diesel fuel blends are used. A local state of the art pertaining to previously conducted research is provided below, followed by the experimental setup, the test plan and the evaluation of the main properties of the fuel blends used in this research. Subsequently, the results obtained in terms of engine performance and emissions will be presented and analyzed. Finally, the main conclusions of the work will be drawn.

Research carried out internationally are taken into account in the results and discussion section; however, in this introduction the most representative studies in Colombia are presented in order to have a clear national panorama. The first studies that were carried out in the country studied blends of biodiesel with conventional Diesel fuel in percentages of $2 \%, 5 \%, 10 \%, 20 \%$ and $30 \%$ of biodiesel content. The biodiesel content effect was determined in an engine at three different atmospheric conditions. Static test bench results showed that the torque and power curves of the engine were similar when using either conventional fuel or biodiesel blends. Only a minimal variation was observed when assessing specific fuel consumption levels.

Additionally, dynamic tests carried out on vehicles determined that the power and torque output decreased by $7 \%$ on average in relation to regular Diesel and 6,2\% in relation to extra Diesel. This data suggests that by increasing the percentage of biodiesel in the blend, the power delivered is reduced. In terms of pollutant emissions, the reduction of particulate matter (PM) was 53\% and 17\% lower when compared to regular and extra Diesel, respectively. The investigation at different atmospheric conditions (meters above sea level) showed that when the atmospheric pressure decreases, emissions are higher due to the lower oxygen concentration. Emissions of carbon dioxide and nitrogen oxides decreased by $7 \%$ and $20 \%$ for ordinary Diesel and $1 \%$ and $12 \%$ with extra Diesel, respectively [10]. 
In other research studies, the impact of liquid biofuels (biodiesel) was compared to conventional fuel. Sulphates are totally reduced, carbon monoxide and hydrocarbons decreased by $44 \%$ and $68 \%$, respectively. The only negative effect is the increase of $\mathrm{NO}_{\mathrm{X}}$ and $15 \%$ power loss. These studies verified an increase in fuel consumption, due to the lower biodiesel calorific value [11]. In 2007, an experimental study was conducted on the production and use of biodiesel from fig oil, which was mixed with conventional Diesel in a proportion of a maximum of $15 \%$ of biodiesel, keeping the quality specifications stipulated for national and international standards for Diesel fuels. The main difficulty of this biodiesel is its high viscosity, since this property directly influences the process of fuel atomization and homogenization of the mixture in the combustion chamber. However, this biofuel presents excellent flow properties at low temperatures, which makes it excellent for cold conditions. Engine tests with castor oil biodiesel blends show that, as the proportion of biodiesel in the blend increases, specific fuel consumption increases, relative metering decreases, smoke opacity decreases slightly, while effective performance and $\mathrm{CO}$ and $\mathrm{CO}_{2}$ emissions remain unchanged [12].

Subsequently, a model of the combustion process was applied to a turbocharged automotive Diesel engine to investigate the effect of different fuels including pure biodiesel, conventional Diesel and blends at 20 and $50 \%$ in volume, operating at the same power. The tests were carried out without any modifications to the engine or fuel injection system. The study indicated that when the concentration of biodiesel in the mixture increases, the ignition delay in the start of combustion and in the fuel/air ratio (dosage) slightly decrease, changing from 0.39 without biodiesel to 0.37 for pure biodiesel. In addition, the thermal efficiency, combustion duration, maximum average temperature inside the cylinder, exhaust gas temperature at the outlet of the exhaust valve and exhaust gas efficiency decreased; conversely, the maximum pressure, specific fuel consumption and exergy rate destroyed increased [13, 14].

Unlike all the studies described above, Acevedo and Mantilla evaluated the performance and emissions of a Cummins Diesel engine, 4 stroke, 9.5 liters, 6 cylinders with common rail injections system, and gas recirculation system. The trials showed a drop in power close to $10 \%$ when African palm biodiesel was used. The engine met the 2004 environmental standard when operated on Diesel fuel. However, whit the alternative fuel, the emissions of particulate matter and nitrogen oxides were beyond the limitations imposed by standard [15]. Finally, mixtures with 10\% and 30\% biodiesel based on palm oil have also been compared with a standard Diesel with ultra-low Sulphur content to evaluate the amount of engine particles emissions and how these affected the performance of aftertreatment devices such as particle filter [16].

\section{EXPERIMENTAL SETUP}

In order to study the impact of different blends of palm biodiesel produced in Colombia and standard Diesel fuel in a Diesel engine performance, a static test bench was used. The test bench has a hydraulic brake, which enables to control engine speed, brake applied to the crankshaft and engine load (fuel flow through the accelerator) [17]. The engine specifications are presented in Table 1.

Table 1. Isuzu C223 turbo engine specifications

\begin{tabular}{ll}
\hline Engine type & 4 strokes / indirect injection \\
Combustion Chamber type & Swirl \\
Total displacement of the pistons & $2238 \mathrm{cc}$ \\
Compression ratio & $21: 1$ \\
Intercooler and EGR & No \\
Pump and injector & Mechanical performance \\
Environmental standards & Pre-Euro \\
\hline
\end{tabular}

The temperatures in the heat exchanger, in the engine and in the exhaust were measured in an attempt to control engine operation; the blowby, the oil pressure, the air flow, the engine torque, the speed and the environmental conditions at which the engine was operating were measured as well. All these measurements were recorded with a data acquisition system (called SMAC), a system that monitors all the values on a control panel screen. An opacimeter was used to measure smoke density and a portable analyzer was used to record measurements of $\mathrm{NO}_{\mathrm{X}}$ pollutant emissions. Additionally, a gravimetric balance measured the engine fuel consumption while a thermocouple was installed to measure fuel temperature at the fuel pump inlet. Table 2 shows the accuracy of the most important equipments and sensors employed in this study and Figure 1 shows the scheme of the experimental setup.

Table 2. Characteristics of measuring equipment used in the workplace

\begin{tabular}{lll}
\hline Equipment or Sensor & Variable & Precision \\
\hline Load cell (up to $250 \mathrm{~kg}$ ) & Torque & $0,1 \mathrm{Nm}$ \\
Gravimetric balance (up to $30 \mathrm{~kg}$ ) & Fuel mass & $1 \mathrm{~g}$ \\
Smoke meter & Smoke density $\left[\mathrm{m}^{-1}\right]$ & $0,01 \mathrm{~m}^{-1}$ \\
Portable analyzer & $\mathrm{NO}_{\mathrm{X}}$ & $5 \mathrm{ppm}$ \\
\hline
\end{tabular}




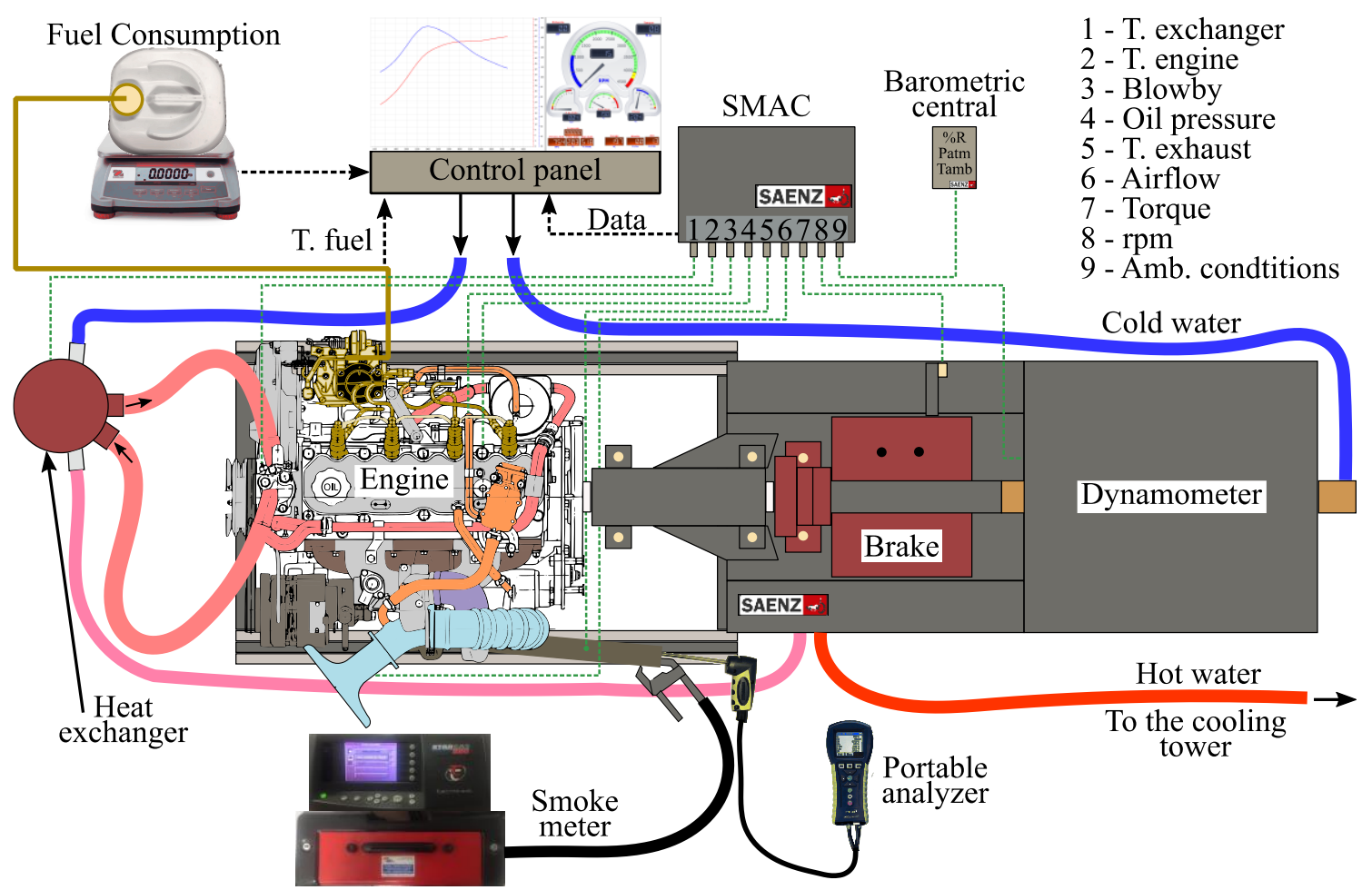

Figure 1. Experimental setup

\section{Biodiesel Blends}

Three different biodiesel and standard Diesel fuel blends were defined to study the influence of palm biodiesel produced in Colombia on engine performance and the related pollutants emissions level associated to each blend. The volumetric concentration of biodiesel in standard Diesel fuel was established at $25 \%, 50 \%$ and $75 \%$. It is important to note that standard Diesel currently produced and marketed in Colombia contains approximately $10 \%$ of biodiesel. As such, it was necessary to verify the biodiesel content of standard Diesel, to calculate the required volume to achieve the target biofuel content for each one of the blends.

The properties of five different types of fuels (including standard Diesel B10 and pure palm oil biodiesel B100) were obtained in order to understand their influence on the engine performance. The properties of the tested fuels are presented in Table 3. The cetane index is a theoretical approximation of the cetane number. This figure was calculated from the density and distillation of the fuel (using ASTM D976).

Table 3. Basic properties of used fuels

\begin{tabular}{ccccc}
\hline Fuel & $\begin{array}{c}\text { Density } \\
{\left[\mathbf{k g} / \mathbf{m}^{3}\right]}\end{array}$ & $\begin{array}{c}\text { Cetane index } \\
{[-]}\end{array}$ & $\begin{array}{c}\text { Higher calorific value } \\
{[\mathbf{k J} / \mathbf{k g}]}\end{array}$ & $\begin{array}{c}\text { Viscosity at } \mathbf{4 0}^{\circ} \mathbf{C} \\
{[\mathbf{c S t} \text { ] }}\end{array}$ \\
\hline B10 & 0,8621 & 39,855 & 44680 & 3,896 \\
B25 & 0,8637 & 45,181 & 43820 & 3,988 \\
B50 & 0,8670 & 47,474 & 42520 & 4,141 \\
B75 & 0,8713 & 47,367 & 41055 & 4,294 \\
B100 & 0,8763 & 46,591 & 39025 & 4,448 \\
\hline
\end{tabular}

The test plan is presented in Table 4. For each fuel, the engine was operated at different engine load levels and engine speed. The test plan included a total of 125 tests which were performed at maintained the same injection timing (mechanical pump with the same advance position for all points tested).

The experimental procedure consisted in starting the engine and allowing for it to stabilize up to the engine operating temperature (close to $80^{\circ} \mathrm{C}$ ). Afterwards, the engine speed was gradually increased for each fuel until the engine reached its maximum load (full accelerator). The hydraulic brake was modulated to vary the engine speed from $1500 \mathrm{rpm}$ to 3500 rpm. For each stabilized condition, the performance and emissions data were acquired. Then, the load was decreased to $90 \%, 80 \%, 70 \%$, and $60 \%$, acquiring again the data between $1500 \mathrm{rpm}$ and $3000 \mathrm{rpm}$. The procedure was repeated for each tested fuel, considering that after a fuel change, before starting to acquire new data, the engine was run to consume approximately 5 liters $\left(5 \times 10^{-3} \mathrm{~m}^{3}\right)$ of the new fuel to ensure that the entire fuel system had no trace of the old fuel. 
Table 4. Test plan

\begin{tabular}{ccc}
\hline Fuel & Load [\%] & Engine speed [rpm] \\
\hline B10 & $100,90,80,70,60$ & $1500,2000,2500,3000,3500$ \\
B25 & $100,90,80,70,60$ & $1500,2000,2500,3000,3500$ \\
B50 & $100,90,80,70,60$ & $1500,2000,2500,3000,3500$ \\
B75 & $100,90,80,70,60$ & $1500,2000,2500,3000,3500$ \\
B100 & $100,90,80,70,60$ & $1500,2000,2500,3000,3500$ \\
\hline
\end{tabular}

\section{RESULTS AND DISCUSSION}

This section presents the results of the performance and pollutant emissions assessment of a Diesel engine when different biodiesel blends are used. As a starting point, the power, the torque, the mean effective pressure (mep) and the brake specific fuel consumption (BSFC), for each condition (see Table 4) will be evaluated. Then, the results of pollutant emissions, which were measured simultaneously with engine performance, will be analyzed.

\section{Performance Results}

As shown in Figure 2, the measured trend in engine torque output is similar for all fuels. With increasing speed, the torque begins to increase until it reaches approximately $2300 \mathrm{rpm}$ and then it drops rapidly until the highest engine speed is reached. As the load decreases, the torque drops too.
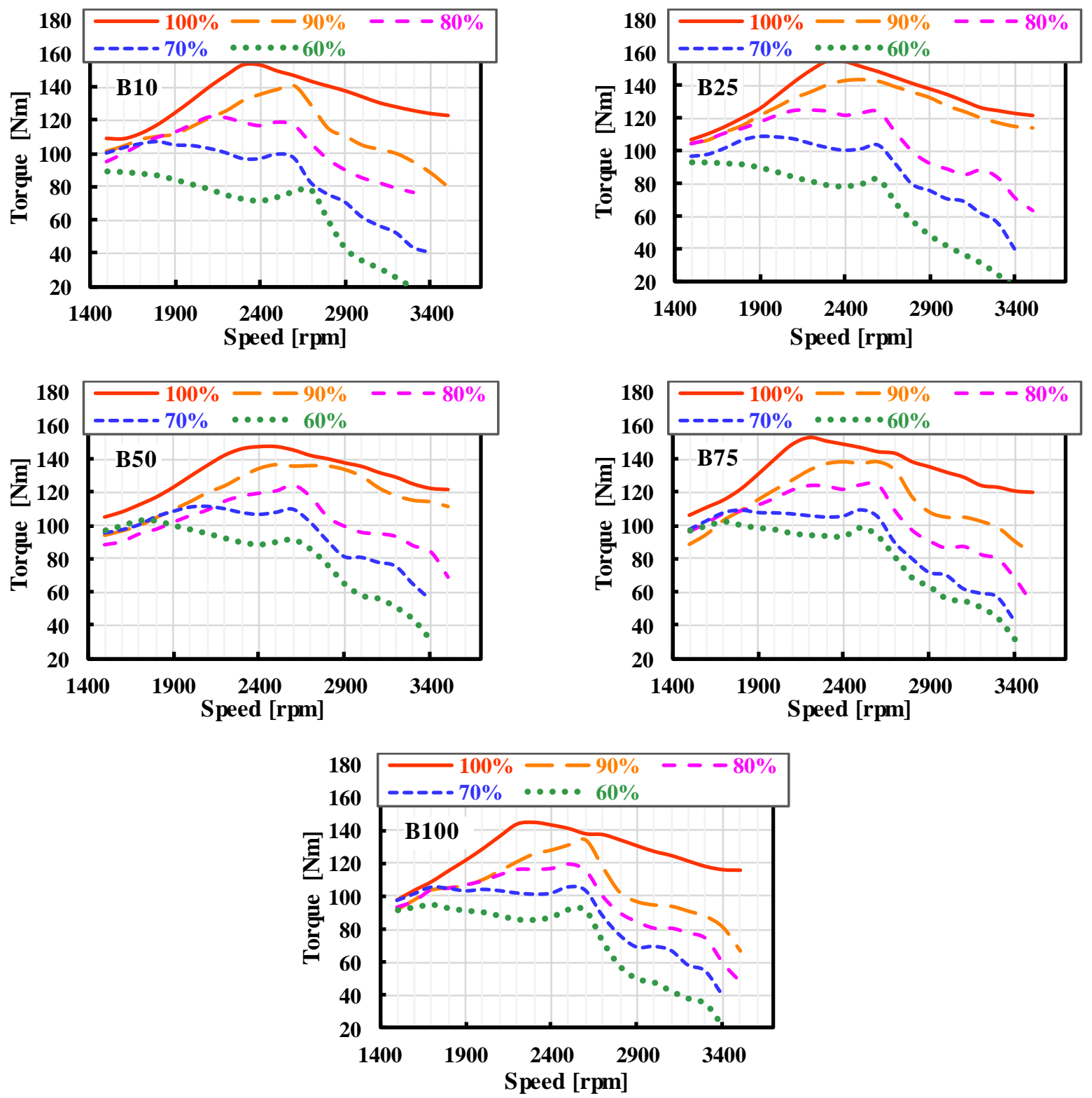

Figure 2. Torque for each fuel blend at different operating conditions 
A similar trend is observed when analyzing the engine power output (see Figure 3 ). With regards to the volume of fuel injected, it is important to underscore that there are no significant variations in the torque and power when using different fuel blends on each one of the loads. However, it is possible to find slight reductions in parameters associated with the fuels' released heat as it has occurred in other studies [18]; because the calorific value of biodiesel blends is lower, compared with that of standard Diesel, there could be a drop in the levels of released heat. In general, when using B 100, both torque and power are only reduced by $8 \%$ to $9 \%$ compared to the B10, comparing the maximum performance points on all loads.
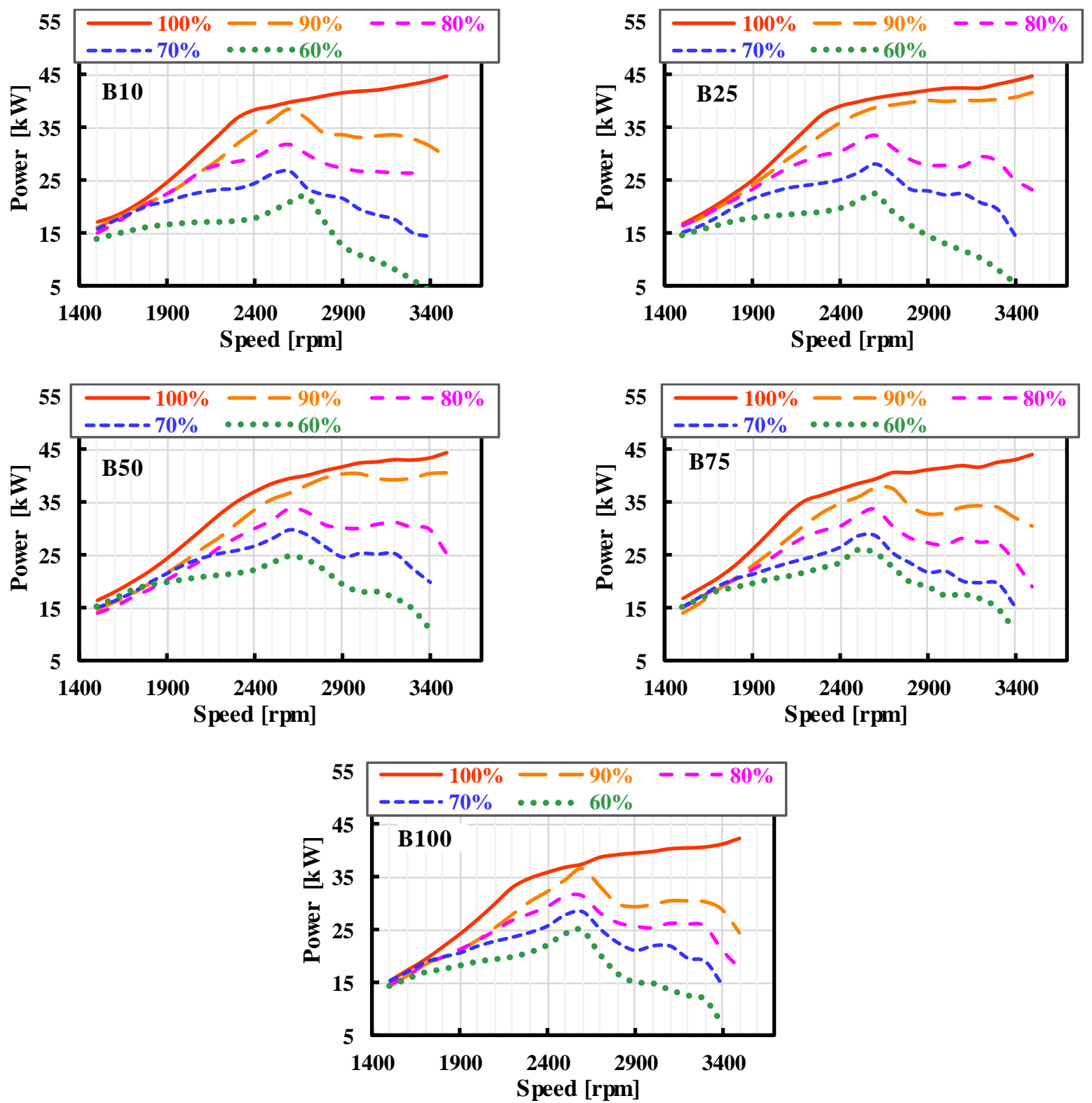

Figure 3. Power for each fuel blend at different operating conditions

Brake specific fuel consumption reflects the efficiency of the fuel used and the effective power it produces. In Figure 4 , brake specific fuel consumption increases when the engine is run with biodiesel blends. These results stem from the lower-than-standard Diesel calorific value of biodiesel blends, as shown in Table 3. As a consequence, the calorific value of the biodiesel blends decreases in proportion to the increase of the biodiesel content, causing an increase of the fuel consumption. It is also known that it is necessary to use more fuel to develop the same torque with biodiesel blends compared to standard Diesel fuel. Compared to the B10, the variations in specific fuel consumption are 3.7\%, 7.0\%, 9.4\% and $13.2 \%$ for the B25, B50, B75 and B100, respectively. This observation is in agreement with other studies showing that the biodiesel blends that have a lower calorific value when compared to standard Diesel, resulted in higher fuel engine requirement to achieve the same performance, eventually affecting the brake specific fuel consumption [15, 19, 20]. 

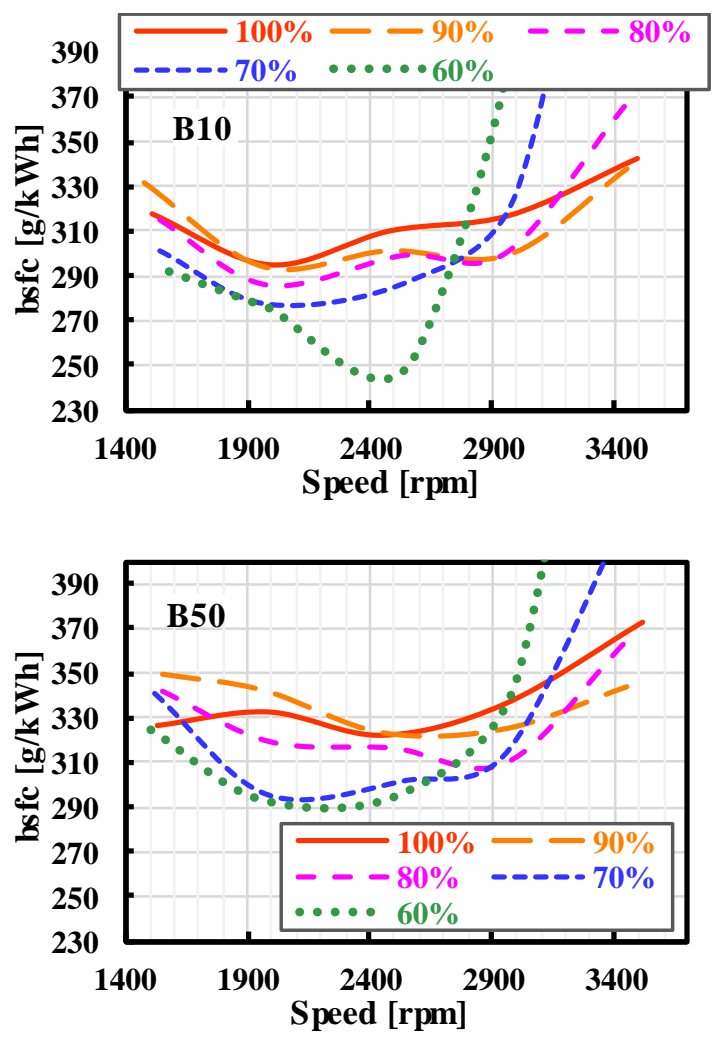
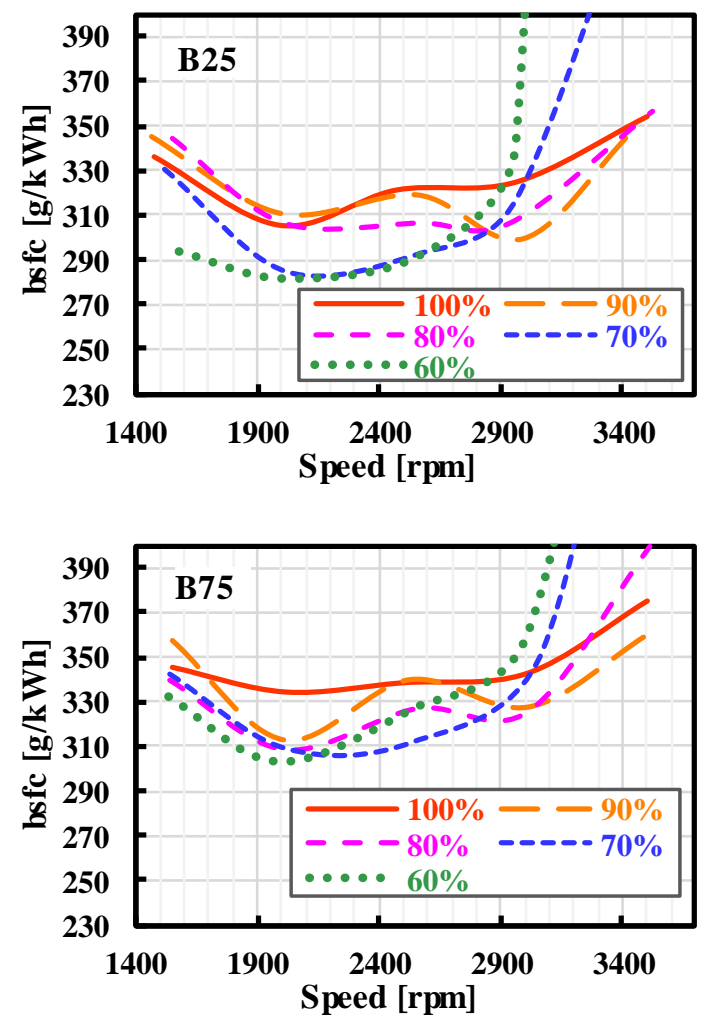

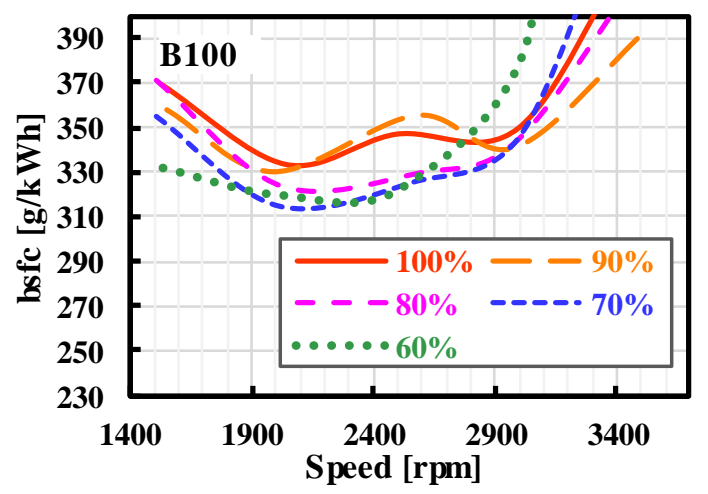

Figure 4. BSFC for each fuel blend at different operating conditions

The trend of the thermal efficiency, which is the inverse of the product of the brake specific fuel consumption and the calorific value, is also studied. In Figure 5, few variations are observed in terms of the thermal efficiency for all fuel blends and loads, although a higher brake specific fuel consumption is observed (Figure 4), the calorific value decreases as the biofuel content increases (see Table 3), compensating the total heat added to the engine. The result is a similar thermal efficiency,regardless of the fuel blends or loads used. In addition, because of the higher viscosity of biodiesel blends, the atomization of the fuel is not as effective. Accordingly, the lack of efectivness on atomization rates has a negative effect on the combustion process and engine performance. This effect was also shown in other investigations on biodiesel blends [20, 21].

According to Canakci [22], while using a B100 soybean oil in a turbo-charged, four-stroke, direct injection diesel engine, specific fuel consumption increases by $13.8 \%$ to reach the same power as conventional Diesel. Kegl evidenced a similar behavior when using rapeseed oil. A B100 based on rapeseed oil produced a decrease of about $10 \%$ in the effective power and torque of the engine, plus an increase in the specific fuel consumption due to the lower calorific value of the fuel [23]. To improve these parameters, sometimes additives are added to the blend to improve torque, power and mean effective pressure when using biodiesel [24]. 

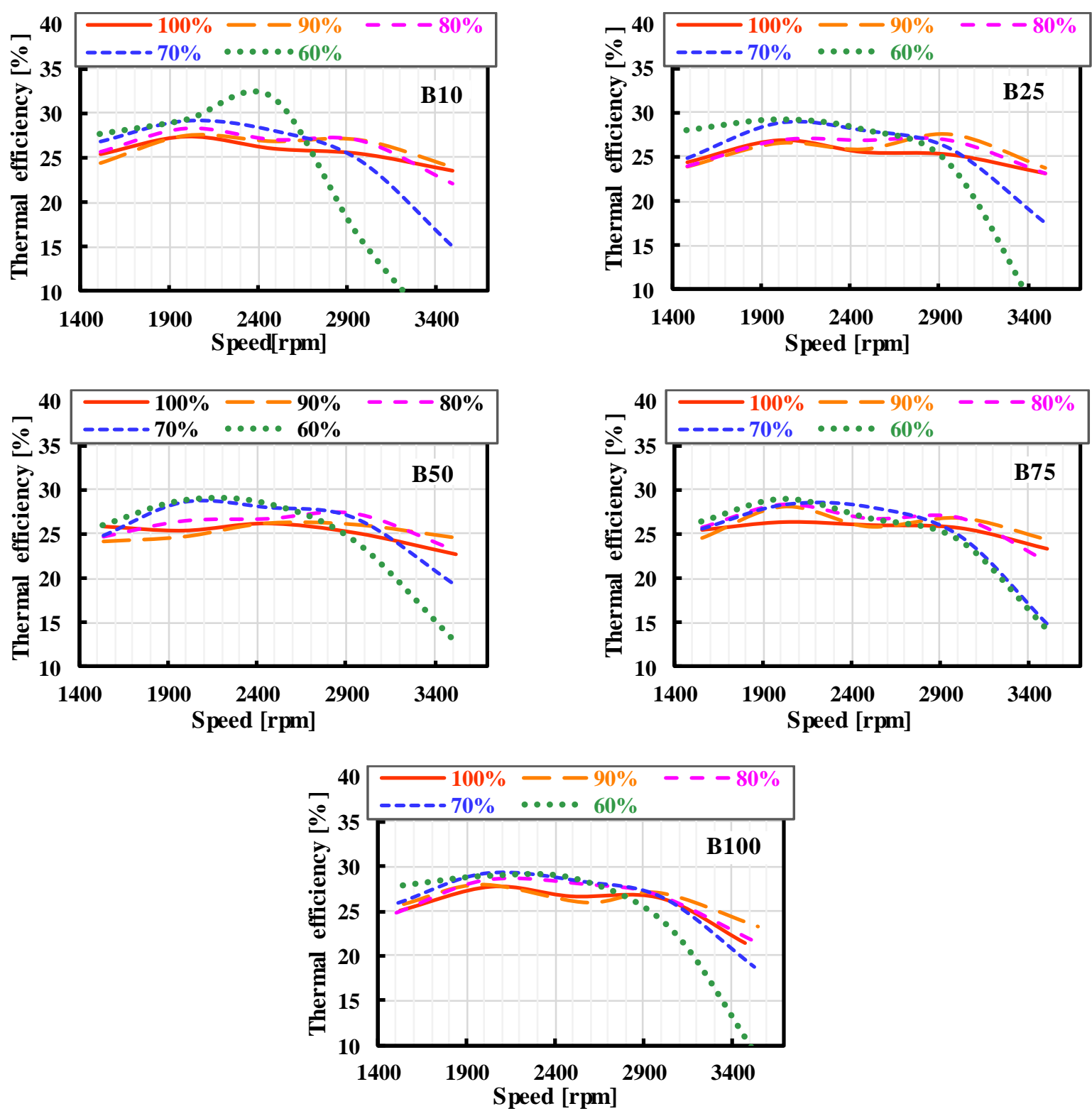

Figure 5. Effective thermal efficiency for each fuel blend at different operating conditions

\section{Pollutant Emissions Results}

Results of smoke emissions are presented in Figure 6. Regardless of the load, the maximum levels of this pollutant are found at lower engine speed. When comparing Figure 6 with Figure 3, the lowest power levels are found at the same low engine speed, which can be interpreted as an increase in fuel/air ratio (dosage). On the other hand, as the operating load of the engine decreases, smoke density levels drop. There is no significant impact of the load from 3000 rpm onwards.

A greater reduction in smoke density levels is achieved with biodiesel blends, compared to conventional Diesel fuel, as the alternative fuel content increases in the blend. Accordingly, Lapuerta [25] and Wang [26] stated that the most important factor contributing to smoke reduction is the oxygen content of the alternative fuel molecule, which allows a more complete combustion even in regions of the combustion chamber where rich mixtures are present, thus aiding in the oxidation of the soot already formed. The lower end of boiling point of biodiesel blends in relation to conventional Diesel fuel ensures complete evaporation of the liquid fuel, which also helps to reduce smoke levels [27]. Under low engine speed conditions (1500 to $2000 \mathrm{rpm}$ ) and for all loads, the reduction in smoke density levels relative to the B10, are $3.9 \%, 7.0 \%, 32.1 \%$ and $48 \%$ for the $\mathrm{B} 25, \mathrm{~B} 50, \mathrm{~B} 75$ and B100, respectively.

Additionally, according to Yoon et al. [28], pure biodiesel provides about $11 \%$ in mass of molecular oxygen and has a negligible content of sulfur and aromatics (which are precursors of this pollutant), two explanatory factors as to why smoke emissions are reduced with these types of fuel. An increase in biofuel content also generates an advance in the combustion process since biodiesel features a higher cetane index values compared to conventional Diesel [29], triggering a reduction in the ignition delay, better ignition performance and higher combustion efficiency [30]. 

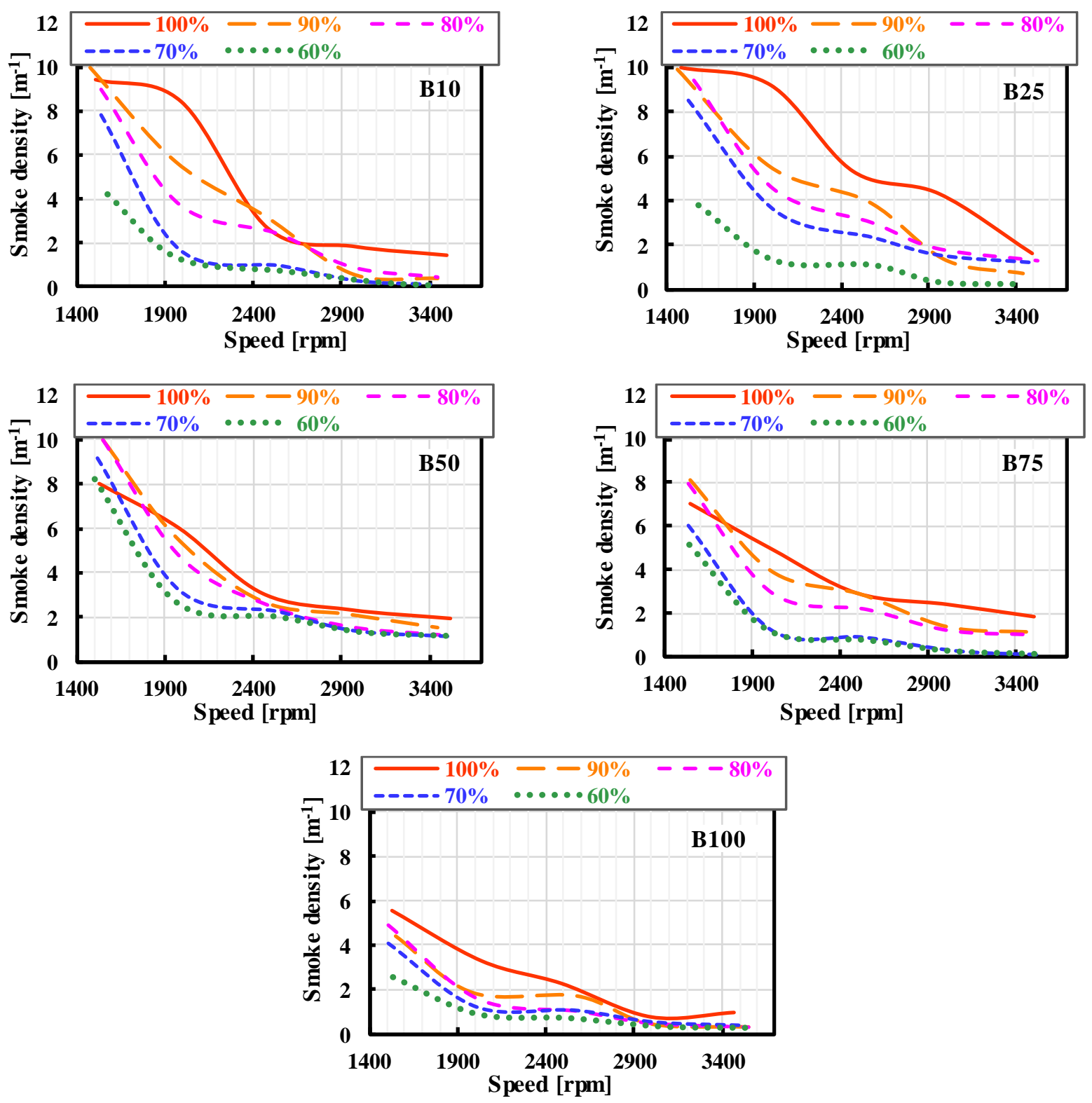

Figure 6. Smoke density for each fuel blend at different operating conditions

However, engine speed and load did not show any significant impact on NOx emissions, as shown in Figure 7. On the one hand, it is said that the increase in $\mathrm{NO}_{\mathrm{X}}$ is related only to fuel properties, so the higher cetane number of biodiesel blends, compared to standard Diesel, leads to shorter delay times. This effect causes a reduction in pressures and temperatures during the diffusion combustion phase, and eventually results in an increase in the formation of $\mathrm{NO}_{\mathrm{X}}$, [25, $28,31]$. In fact, the highest combustion temperature occurs in the pre-mixed combustion phase and it is during this phase that most of this pollutant is formed, especially if the air/fuel mixtures are close to stoichiometry [32]. On the other hand, other studies show that with biodiesel there is an improvement in ignition time, which leads to higher temperatures inside the cylinder [33]. Finally, the increase in $\mathrm{NO}_{\mathrm{X}}$ can be attributed to the fact that biodiesel has a more complete combustion, due to the greater presence of oxygen in the combustion chamber [18]. In many researchers have found that adding biodiesel to diesel will increase NOx emissions [34-37].

In addition, depending on the engine operating conditions, a set of effects (physical-chemical processes during combustion) can counteract or enhance each other, affecting $\mathrm{NO}_{\mathrm{X}}$ formation process. For example, $\mathrm{NO}_{\mathrm{X}}$ emissions are believed to be directly dependent on the engine load, because the internal temperature of combustion chamber rises and the formation of this pollutant generally depends largely on the temperature phenomenon [38, 39].

In certain situations, biodiesel and Diesel blends have shown reductions in $\mathrm{NO}_{\mathrm{X}}$ emissions despite their inherent higher oxygen content. In addition to the aforementioned academic work, other studies [34, 40, 41] report that blends featuring biodiesel concentrations lower that $10 \%$, can lead to a reduction in NOx emissions. This fact might be related to the soot particles radiation emissions and the consequent reduction of the combustion temperature, which results eventually in lower $\mathrm{NO}_{\mathrm{X}}$ emissions. It is also said that the extra oxygen content of biodiesel allows the engine to work with poorer global dosage, which also generates lower temperatures in the combustion chamber. Additionally, combustion occurs in those areas with dosing close to stoichiometric and, in biodiesel, this dosing value is lower [42]. 

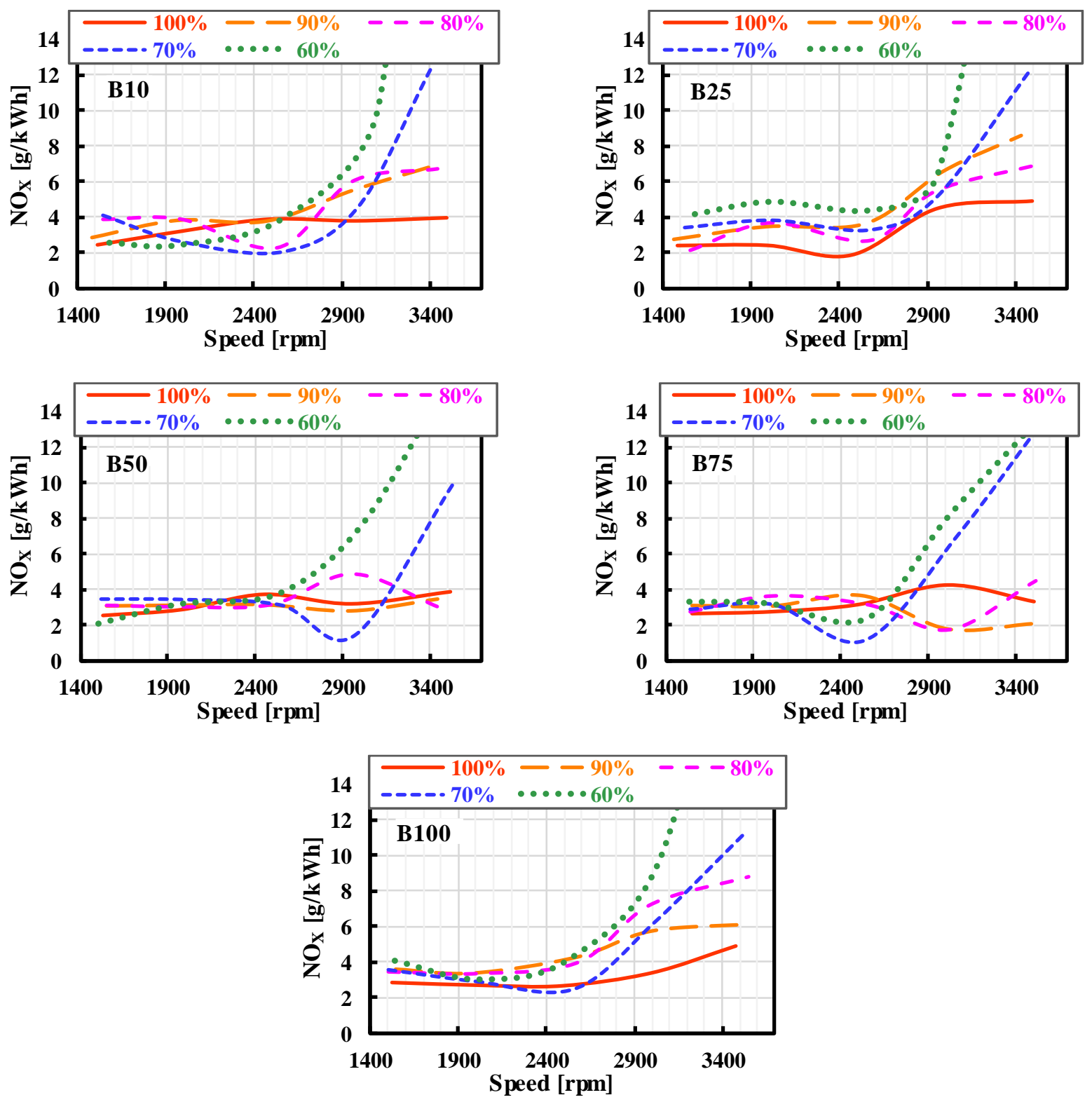

Figure 7. $\mathrm{NO}_{\mathrm{X}}$ for each fuel blend at different operating conditions

It was possible to simultaneously reduce smoke density and $\mathrm{NO}_{\mathrm{X}}$ levels in $16 \%$ of all the established engine operating points, compared to standard fuel (B10). These scenarios were generally obtained at low engine speed (1500 to $2500 \mathrm{rpm}$ ) and high load conditions (100\% to $80 \%$ ).

As expected, this study confirms the trade-off between $\mathrm{NO}_{\mathrm{X}}-\mathrm{PM}$, which states that it is not easy to reduce both pollutant emissions simultaneously in Diesel engines, since they have opposite developments [43, 44]. Figure 8 shows a set of conditions when $\mathrm{NO}_{\mathrm{X}}$ levels decrease is followed by an increase in opacity, due to particle radiation, causing a reduction in combustion temperature and consequently reduction of $\mathrm{NO}_{\mathrm{X}}$ [45-47]. 

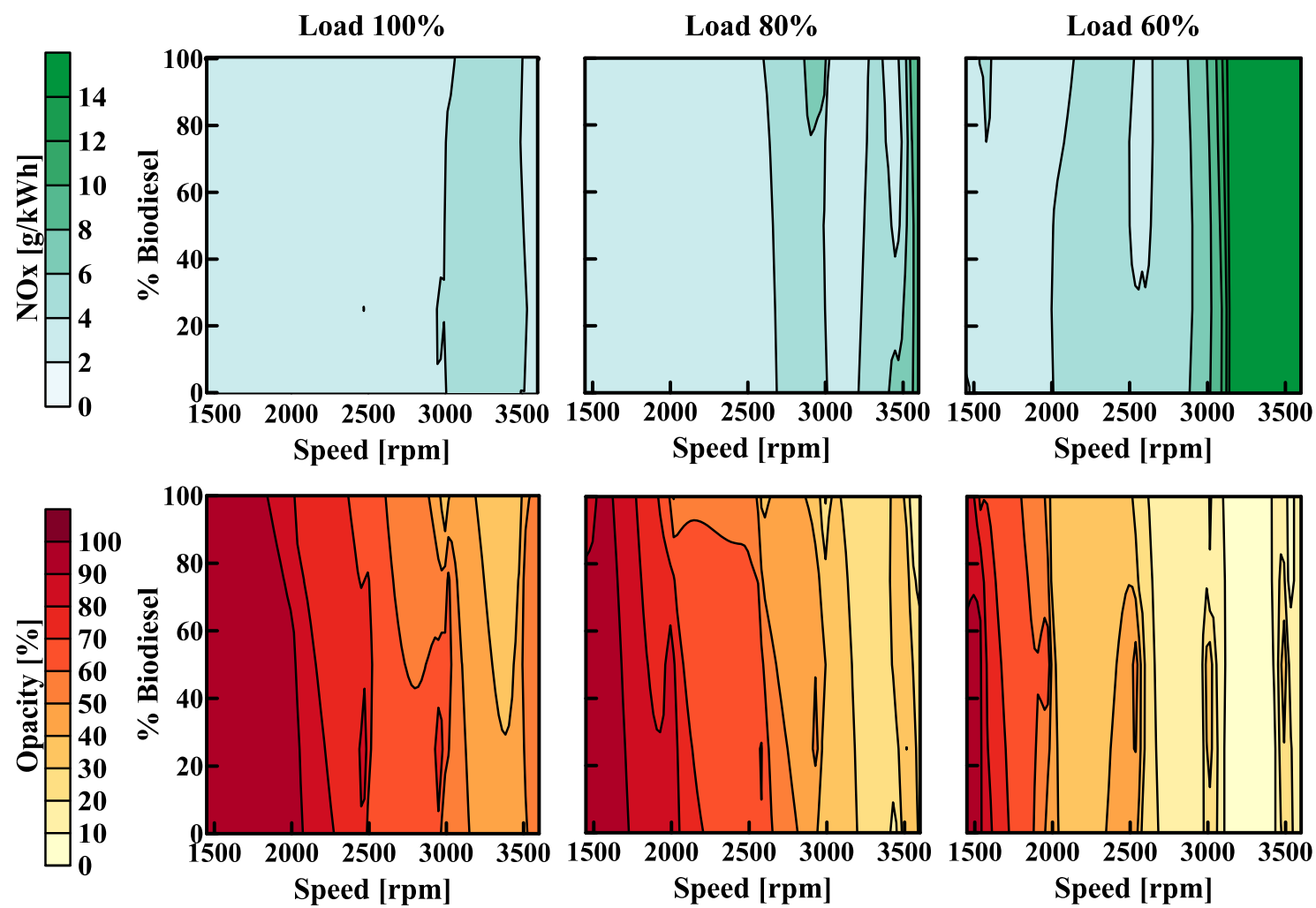

Figure 8. Trade off NOx-opacity for each fuel blend at different operating conditions

\section{CONCLUSIONS}

The main conclusions of this study are shown below:

- Palm oil derived biodiesel (B100) has a calorific value 13\% lower than commercial Diesel. This trait affects the power delivered by the engine and/or the fuel consumption generating an increase in specific fuel consumption $(13,2 \%)$. For the blends B25, B50 and B75, the decrease in calorific value was $2 \%, 5 \%$ and $8 \%$ respectively, compared to the B10.

- It was observed that the maximum engine performance (torque and power) drops only between $8 \%$ and $9 \%$ when using pure biodiesel (B100) compared to B10 fuel, which is an acceptable range for all loads tested for which nearly the same thermal efficiency was maintained.

- The cetane index of biodiesel is $17 \%$ higher than commercial fuel, which can have a positive effect on the start of the combustion process by reducing the ignition delay time. In future works, the ignition advance could be modified according to the cetane index of each mixture, in order to adjust the combustion phasing and take a better advantage of the characteristics of each fuel.

- When observing the $\mathrm{NO}_{\mathrm{X}}$ per unit of delivered power, this pollutant increased at low load and high engine speeds, independent of the mixture. This fact is attributed to changes in dosing, delay time and especially due to a higher combustion temperature in this area of the engine operation. According to other studies, the use of biodiesel induces higher combustion pressures and temperatures, increasing $\mathrm{NO}_{\mathrm{X}}$ emission's formation; however, in this study no significant changes in $\mathrm{NO}_{\mathrm{X}}$ were observed.

- The reduction in smoke density becomes evident as the biodiesel content in the fuel blend increases. The maximum reduction was of $48 \%$. The most important factor that induces the reduction of opacity is the oxygen content in the biodiesel molecule (oxygenated fuel) which allows for a more complete combustion even in regions close to the walls of the combustion chamber.

- The $\mathrm{NO}_{\mathrm{X}}-\mathrm{PM}$ trade-off was confirmed by showing the conditions in which the $\mathrm{NO}_{\mathrm{X}}$ level decreases. This effect can stem from the increased radiation of the particles (greater opacity) that reduces the combustion temperature and, consequently, NOx formation.

\section{ACKNOWLEDGMENTS}

The researchers are grateful to BioD S.A. company, for having contributed to the development of this research project, delivering the fuel necessary for the tests and for their collaboration in determining the biofuel content of each sample. A special acknowledgement to the engineer M.Sc. Alejandro Muñoz for his cooperation in the management and adjustment 
of the equipment to measure pollutant emissions and to the laboratory technician Dayani Triana for having the necessary elements up to date to properly carry out the testing plan. Finally, thanks to the University of San Buenaventura - Bogotá for their support to the project.

\section{REFERENCES}

[1] L. Mónico, "Contribución al estudio del ruido de combustión en conceptos avanzados de combustión Diesel,” 2013.

[2] N. I. Izzatie, M. H. Basha, Y. Uemura, M. S. M. Hashim, M. Afendi, and M. A. F. Mazlan, "Co-pyrolysis of rubberwood sawdust (RWS) and polypropylene (PP) in a fixed bed pyrolyzer," Journal of Mechanical Engineering and Sciences, vol. 13, no. 1, pp. 4636-4647, Mar. 2019, doi: 10.15282/jmes.13.1.2019.20.0390.

[3] R. Anandhan, S. Karpagarajan, P. Kannan, E. Neducheralathan, J. Arunprasad, and S. Sugumar, "Performance and emission analysis on diesel engine fueled with blends of jojoba biodiesel," Materials Today: Proceedings, Feb. 2021, doi: 10.1016/j.matpr.2021.02.165.

[4] S. R. Kumar and P. S. Chaitanya, "Role of nanoadditive blended biodiesel emulsion fuel on the performance and emission characteristics of diesel engine," Journal of Mechanical Engineering and Sciences, vol. 13, no. 2, pp. 4869-4879, 2019, doi: 10.15282/jmes.13.2.2019.08.0405.

[5] A. J. Torregrosa, A. Broatch, B. Plá, and L. F. Mónico, "Impact of Fischer-Tropsch and biodiesel fuels on trade-offs between pollutant emissions and combustion noise in diesel engines," Biomass and Bioenergy, vol. 52, pp. 22-33, May 2013, doi: 10.1016/j.biombioe.2013.03.004.

[6] Q. Ma, Q. Zhang, J. Liang, and C. Yang, "The performance and emissions characteristics of diesel/biodiesel/alcohol blends in a diesel engine," Energy Reports, vol. 7, pp. 1016-1024, Nov. 2021, doi: 10.1016/j.egyr.2021.02.027.

[7] A. Kondaiah et al., "Influence of blends of castor seed biodiesel and diesel on engine characteristics," in Materials Today: Proceedings, 2020, vol. 45, pp. 7043-7049. doi: 10.1016/j.matpr.2021.01.653.

[8] M. A. Asokan, S. S. Prabu, V. S. Akhil, P. S. Bhuvan, and Y. B. Reddy, "Performance and emission behaviour of diesel and blends of watermelon seed oil biodiesel in direct injection diesel engine," in Materials Today: Proceedings, 2021, vol. 45, pp. 3274-3278. doi: 10.1016/j.matpr.2020.12.469.

[9] Fedebiocombustibles, "Demanda Nacional de Biodiesel," 2019. http://www.fedebiocombustibles.com/v3/estadisticaproduccion-titulo-Biodiesel.htm (accessed Aug. 27, 2021).

[10] M. Cuéllar Sánchez and J. A. Torres, "Posibilidades del biodiésel de palma y sus mezclas con diésel en Colombia," Revista Palmas, vol. 28, 2007.

[11] J. M. Amarís, D. A. Manrique, and J. E. Jaramillo, "Biocombustibles Líquidos en Colombia y su Impacto en motores de combustion interna. Una revisión,” Revista Fuentes el Reventón Energético, vol. 13, no. 2, pp. 23-34, Jul. 2015, doi: 10.18273/revfue.v13n2-2015003.

[12] A. Benavides, P. Benjumea, and G. C. Alternativos, "El Biodiesel de Aceite de Higuerilla como Combustible Alternativo para Motores Diesel," Dyna, vol. 74, pp. 141-150, 2007.

[13] J. Agudelo, E. Gutiérrez, and P. Benjumea, "Experimental combustion analysis of a HSDI diesel engine fuelled with palm oil biodiesel-diesel fuel blends," Dyna, vol. 76, pp. 103-113, 2009.

[14] J. R. Agudelo, A. Agudelo, and J. F. Pérez, "Caracterización de la combustión del biodiesel de aceite de palma en un motor diesel," ResearchGate, 2011, [Online]. Available: https://www.researchgate.net/publication/277161312

[15] H. Acevedo and J. Mantilla, "Performance and Emissions of a Heavy Duty Diesel Engine Fuelled With Palm Oil Biodiesel and Premium Diesel," Dyna, vol. 78, pp. 152-158, 2011.

[16] M. Cadrazco, A. Santamaría, and J. R. Agudelo, "Chemical and nanostructural characteristics of the particulate matter produced by renewable diesel fuel in an automotive diesel engine," Combustion and Flame, vol. 203, pp. 130-142, May 2019, doi: 10.1016/j.combustflame.2019.02.010.

[17] Saenz, "Bancos de Pruebas de Motores," 2019. http://www.saenzdynos.com.ar/ (accessed Aug. 27, 2021).

[18] İ. Sugözü, C. Öner, and Ş. Altun, "The Performance and Emissions Characteristics of a Diesel Engine Fueled with Biodiesel and Diesel Fuel," Int.J.Eng.Research $\backslash \&$ Development, 2010.

[19] C. D. Rakopoulos, K. A. Antonopoulos, D. C. Rakopoulos, D. T. Hountalas, and E. G. Giakoumis, "Comparative performance and emissions study of a direct injection Diesel engine using blends of Diesel fuel with vegetable oils or bio-diesels of various origins," Energy Conversion and Management, vol. 47, no. 18-19, pp. 3272-3287, Nov. 2006, doi: 10.1016/j.enconman.2006.01.006.

[20] M. Venkataswamy, V. R. Krishna, and Y. D. Sekhar, "Performance, Combustion and Emission Characteristics of DI-CI Engine with Corn Biodiesel and its Diesel Blends," International Journal of Engineering Trends and Technology (IJETT). 2014.

[21] X. C. Lu, J. J. Ma, L. B. Ji, and Z. Huang, "Effects of premixed n-heptane from the intake port on the combustion characteristics and emissions of biodiesel-fuelled engines," Proceedings of the Institution of Mechanical Engineers, Part D: Journal of Automobile Engineering, vol. 222, no. 6, pp. 1001-1009, 2008, doi: 10.1243/09544070JAUTO743.

[22] M. Canakci, "Combustion characteristics of a turbocharged DI compression ignition engine fueled with petroleum diesel fuels and biodiesel," Bioresource Technology, vol. 98, no. 6, pp. 1167-1175, Apr. 2007, doi: 10.1016/j.biortech.2006.05.024.

[23] B. Kegl, "Influence of biodiesel on engine combustion and emission characteristics," Applied Energy, vol. 88, no. 5, pp. 18031812, 2011, doi: 10.1016/j.apenergy.2010.12.007. 
[24] S. Al-Fagaan, S. Al-Ajmi, and J. Yamin, "Relative performance of a direct ignition diesel engine using biodiesel as fuel under Magnetic Fuel Conditioner," 2015 International Conference on Sustainable Mobility Applications, Renewables and Technology (SMART). 2015.

[25] M. Lapuerta, O. Armas, and J. Rodríguez-Fernández, "Effect of biodiesel fuels on diesel engine emissions," Progress in Energy and Combustion Science, vol. 34, no. 2. Elsevier Ltd, pp. 198-223, 2008. doi: 10.1016/j.pecs.2007.07.001.

[26] W. G. Wang, D. W. Lyons, N. N. Clark, M. Gautam, and P. M. Norton, "Emissions from nine heavy trucks fueled by diesel and biodiesel blend without engine modification," Environmental Science and Technology, vol. 34, no. 6, pp. 933-939, Mar. 2000, doi: 10.1021/es981329b.

[27] M. Lapuerta, O. Armas, R. Ballesteros, and J. Fernández, "Diesel emissions from biofuels derived from Spanish potential vegetable oils," Fuel, vol. 84, no. 6 SPEC. ISS., pp. 773-780, 2005, doi: 10.1016/j.fuel.2004.11.010.

[28] S. H. Yoon, H. K. Suh, and C. S. Lee, "Effect of spray and EGR rate on the combustion and emission characteristics of biodiesel fuel in a compression ignition engine," in Energy and Fuels, Mar. 2009, vol. 23, no. 3, pp. 1486-1493. doi: 10.1021/ef800949a.

[29] M. Lapuerta, J. Rodríguez-Fernández, and J. R. Agudelo, "Diesel particulate emissions from used cooking oil biodiesel," Bioresource Technology, vol. 99, no. 4, pp. 731-740, Mar. 2008, doi: 10.1016/j.biortech.2007.01.033.

[30] F. S. Mirhashemi and H. Sadrnia, "NOX emissions of compression ignition engines fueled with various biodiesel blends: A review," Journal of the Energy Institute, vol. 93, no. 1. Elsevier B.V., pp. 129-151, Feb. 01, 2020. doi: 10.1016/j.joei.2019.04.003.

[31] S. M. Palash, M. A. Kalam, H. H. Masjuki, B. M. Masum, I. M. Rizwanul Fattah, and M. Mofijur, "Impacts of biodiesel combustion on NOx emissions and their reduction approaches," Renewable and Sustainable Energy Reviews, vol. 23. Elsevier Ltd, pp. 473-490, 2013. doi: 10.1016/j.rser.2013.03.003.

[32] M. Zheng, M. C. Mulenga, G. T. Reader, M. Wang, and D. S.-K. Ting, "Influence of Biodiesel Fuel on Diesel Engine Performance and Emissions in Low Temperature Combustion," SAE Technical Paper, 2006.

[33] A. Schönborn, N. Ladommatos, J. Williams, R. Allan, and J. Rogerson, "The influence of molecular structure of fatty acid monoalkyl esters on diesel combustion," Combustion and Flame, vol. 156, no. 7, pp. 1396-1412, Jul. 2009, doi: 10.1016/j.combustflame.2009.03.011.

[34] J. Calder, M. M. Roy, and W. Wang, "Performance and emissions of a diesel engine fueled by biodiesel-diesel blends with recycled expanded polystyrene and fuel stabilizing additive," Energy, vol. 149, pp. 204-212, Apr. 2018, doi: 10.1016/j.energy.2018.02.065.

[35] J. C. Ge, H. Y. Kim, S. K. Yoon, and N. J. Choi, "Reducing volatile organic compound emissions from diesel engines using canola oil biodiesel fuel and blends," Fuel, vol. 218, pp. 266-274, Apr. 2018, doi: 10.1016/j.fuel.2018.01.045.

[36] A. E. Özçelik, H. Aydołan, and M. Acarołlu, "Determining the performance, emission and combustion properties of camelina biodiesel blends," Energy Conversion and Management, vol. 96, pp. 47-57, May 2015, doi: 10.1016/j.enconman.2015.02.024.

[37] L. A. Raman, B. Deepanraj, S. Rajakumar, and V. Sivasubramanian, "Experimental investigation on performance, combustion and emission analysis of a direct injection diesel engine fuelled with rapeseed oil biodiesel," Fuel, vol. 246, pp. 69-74, Jun. 2019, doi: 10.1016/j.fuel.2019.02.106.

[38] U. Rajak, P. Nashine, and T. N. Verma, "Assessment of diesel engine performance using spirulina microalgae biodiesel," Energy, vol. 166, pp. 1025-1036, Jan. 2019, doi: 10.1016/j.energy.2018.10.098.

[39] P. Benjumea, J. R. Agudelo, and A. F. Agudelo, "Effect of the degree of unsaturation of biodiesel fuels on engine performance, combustion characteristics, and emissions," Energy and Fuels, vol. 25, no. 1, pp. 77-85, Jan. 2011, doi: 10.1021/ef101096x.

[40] A. B. Koc and M. Abdullah, "Performance and NOx emissions of a diesel engine fueled with biodiesel-diesel-water nanoemulsions," Fuel Processing Technology, vol. 109, pp. 70-77, 2013, doi: 10.1016/j.fuproc.2012.09.039.

[41] S. Lahane and K. A. Subramanian, "Effect of different percentages of biodiesel-diesel blends on injection, spray, combustion, performance, and emission characteristics of a diesel engine," Fuel, vol. 139, pp. 537-545, Jan. 2015, doi: 10.1016/j.fuel.2014.09.036.

[42] J. R. Agudelo, I. D. Bedoya, and A. F. Agudelo, "Emisiones gaseosas y opacidad del humo de un motor operando con bajas concentraciones de biodiesel de palma," Ingeniería y Desarrolllo, 2005.

[43] M. Torres García, F. José Jiménez-Espadafor Aguilar, and T. Sánchez Lencero, "Experimental study of the performances of a modified diesel engine operating in homogeneous charge compression ignition (HCCI) combustion mode versus the original diesel combustion mode," Energy, vol. 34, no. 2, pp. 159-171, 2009, doi: 10.1016/j.energy.2008.11.002.

[44] R. Diwakar and S. Singh, "NOx and soot reduction in diesel engine premixed charge compression ignition combustion: A computational investigation," International Journal of Engine Research, vol. 9, no. 3, pp. 195-214, 2008, doi: 10.1243/14680874JER00308.

[45] D. Agarwal, S. K. Singh, and A. K. Agarwal, "Effect of Exhaust Gas Recirculation (EGR) on performance, emissions, deposits and durability of a constant speed compression ignition engine," Applied Energy, vol. 88, no. 8, pp. 2900-2907, 2011, doi: 10.1016/j.apenergy.2011.01.066.

[46] J. E. Dec, “Advanced compression-ignition engines - Understanding the in-cylinder processes," Proceedings of the Combustion Institute, vol. 32 II, pp. 2727-2742, 2009, doi: 10.1016/j.proci.2008.08.008.

[47] R. Dijkstra, G. di Blasio, M. Boot, C. Beatrice, and C. Bertoli, "Assessment of the effect of low cetane number fuels on a light duty CI engine: Preliminary experimental characterization in PCCI operating condition,” 2011. doi: 10.4271/2011-24-0053. 